\title{
Imaging probes for non-invasive tumoral detection and functional monitoring of cancer multidrug resistance
}

\author{
Filipa Mendes ${ }^{1, \#}$, Lurdes Gano ${ }^{1, \#}$, Jorge Grilo, ${ }^{1,2}$, Susana Cunha', Célia Fernandes', António Paulo \\ 'DECN-Department of Nuclear Engineering and Sciences and C2TN - Center for Nuclear Sciences and Technologies, Instituto \\ Superior Técnico, Universidade de Lisboa, Estrada Nacional 10, Bobadela LRS 2695-066, Portugal. \\ 2(Present adress) iMed.Ulisboa - Research Institute for Medicines, Faculdade de Farmácia, Universidade de Lisboa, Av. Professor \\ Gama Pinto, Lisboa 1649-003, Portugal. \\ \#Authors contributed equally.
}

Correspondence to: Dr. Filipa Mendes, Department of Nuclear Engineering and Sciences and C ${ }^{2} \mathrm{TN}$ - Center for Nuclear Sciences and Technologies, Instituto Superior Técnico, Universidade de Lisboa, Estrada Nacional 10, Bobadela LRS 2695-066, Portugal. E-mail:fmendes@ctn.tecnico.ulisboa.pt

\begin{abstract}
How to cite this article: Mendes F, Gano L, Grilo J, Cunha S, Fernandes C, Paulo A. Imaging probes for non-invasive tumoral detection and functional monitoring of cancer multidrug resistance. Cancer Drug Resist 2020;3:209-24. http://dx.doi.org/10.20517/cdr.2019.86
\end{abstract}

Received: 29 Sep 2019 First Decision: 12 Dec 2019 Revised: 8 Jan 2020 Accepted: 3 Feb 2020 Available online: 20 Feb 2020

Science Editor: Godefridus J. Peters Copy Editor: Jing-Wen Zhang Production Editor: Jing Yu

\begin{abstract}
Aim: Several cationic radiotracers originally developed as myocardial perfusion agents have shown potential for both early detection of cancer and non-invasive monitoring of multiple drug resistance (MDR) by single photon emission computed tomography. We have introduced two cationic complexes, ${ }^{99 m}$ Tc-DMEOP [di-methoxy-tris-pyrazolyl-

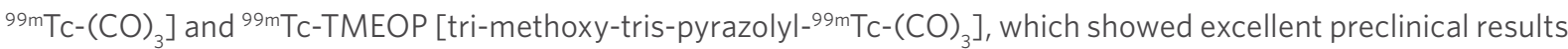
as cardiac imaging probes, namely a persistent heart uptake with rapid blood and liver clearance. This study aimed at the evaluation of their usefulness for tumoral detection and functional assessment of MDR.
\end{abstract}

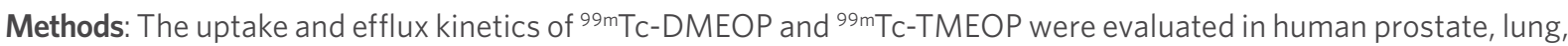
and breast cancer cell lines, including drug-resistant cell lines that are known to overexpress the MDR P-glycoprotein (Pgp). The effects of MDR modulators were also studied. In vivo studies were performed in xenografted tumor models, and the MDR phenotype of the tumors was confirmed by Western blot.

Results: The uptake kinetics of both complexes in human cancer cell lines is comparable with the one found for

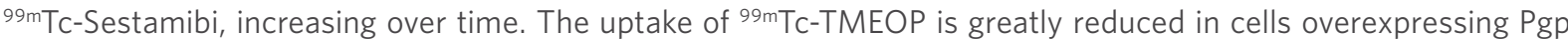

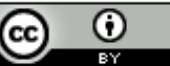

(C) The Author(s) 2020. Open Access This article is licensed under a Creative Commons Attribution 4.0 International License (https://creativecommons.org/licenses/by/4.0/), which permits unrestricted use, sharing, adaptation, distribution and reproduction in any medium or format, for any purpose, even commercially, as long as you give appropriate credit to the original author(s) and the source, provide a link to the Creative Commons license, and indicate if changes were made. 
and increased in the presence of a Pgp modulator. In nude mice, the tumor uptake of ${ }^{99 \mathrm{~m} T c-T M E O P}$ was higher in the MCF-7 xenografts compared with the MCF7 Pgp tumors.

Conclusion: The uptake kinetics of both complexes in human cancer cell lines is comparable with the one found for ${ }^{99 \mathrm{~m} T c-S e s t a m i b i, ~ i n c r e a s i n g ~ o v e r ~ t i m e . ~ T h e ~ u p t a k e ~ o f ~}{ }^{99 \mathrm{~m} T \mathrm{Tc}-T M E O P}$ is greatly reduced in cells overexpressing Pgp, and increased in the presence of a Pgp modulator. In nude mice, the tumor uptake of ${ }^{99 \mathrm{~m} T c-T M E O P}$ was higher in the MCF-7 xenografts compared with the MCF7 Pgp tumors.

Keywords: Noninvasive imaging, imaging probes, tumoral detection, multiple drug resistance, P-glycoprotein

\section{INTRODUCTION}

Cancer is a leading cause of death worldwide. The World Health Organization reported that cancer accounted for 9.6 million deaths (around $17 \%$ of all deaths worldwide) in $2018^{[1]}$.

A major obstacle to successful cancer chemotherapy is drug resistance ${ }^{[2,3]}$. Many tumors are intrinsically resistant to chemotherapy (e.g., kidney, pancreas, liver, and colon), whereas others initially respond to treatment, but acquire resistance to selected cytotoxic drugs during chemotherapy. One form of resistance, so-called multidrug resistance (MDR), is responsible for the failure of tumors to respond to a wide spectrum of chemotherapeutic agents ${ }^{[2,3]}$.

Numerous mechanisms have been proposed to mediate intrinsic or acquired MDR in cancer cells ${ }^{[4]}$. MDR can result from non-cellular mechanisms such as limited vascular accessibility or from cellular mechanisms including modification of the drug target, changes in ability to repair DNA following druginduced damage, disruptions in apoptotic pathways, and changes in the expression of proteins and enzymes associated with tumor resistance. To date, the most widely studied cellular mechanisms of tumor resistance are those associated with drug efflux mechanisms involving members of the adenosine triphosphate (ATP)binding cassette $(\mathrm{ABC})$ membrane transporter family, most importantly P-glycoprotein (Pgp), but also multidrug-resistant protein 1 (MRP1) and homologs (MRP2-6) and breast cancer resistance protein (BCRP). These transporters are found in normal cells, where their role has been identified as one of protection against, and clearance of, excessive extracellular and intracellular concentrations of xenobiotics and toxins. An overarching feature of $\mathrm{ABC}$ transporter-expressing tumor cells is their reduced ability to accumulate certain cytotoxic agents intracellularly, resulting in ineffective cellular levels that fail to bring about cell $\operatorname{death}^{[3,4]}$.

Measurement of MDR is one potentially important marker in planning systemic therapy, as accurate selection of chemosensitive patients would result not only in effective treatment of patients and avoidance of potentially toxic side effects but also in significant cost savings for health care providers without a significant loss of life expectancy for patients ${ }^{[5,6]}$.

The methodologies for the determination of mRNA and protein levels are important for assessing Pgp expression, but they have poor sensitivity and specificity and fail to provide functional information. Therefore, methods for functionally interrogating Pgp, MRP1, and BCRP transport activity have been sought, as this type of phenotypic evaluation is very important to avoid ineffective and potentially toxic treatments ${ }^{[5]}$. Significant effort has been directed toward the non-invasive detection of transportermediated resistance using radiopharmaceuticals characterized as transport substrates for Pgp and other MDR proteins (for review, see ${ }^{[7,8]}$ ). 


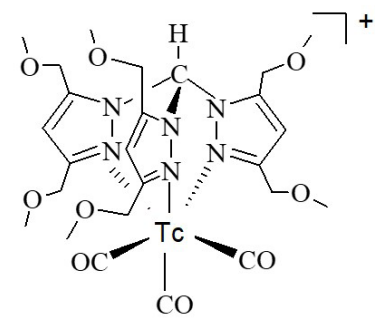

99mTC-DMEOP

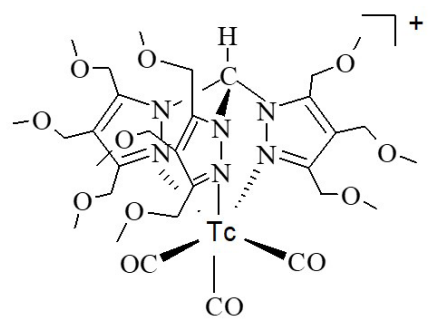

99m TC-TMEOP

Figure 1. Structure of ${ }^{99 \mathrm{~m}} \mathrm{Tc}-\mathrm{DMEOP}$ and ${ }^{99 \mathrm{~m}} \mathrm{Tc}-\mathrm{TMEOP}$ complexes

Despite of an incomplete understanding of the transport mechanisms, several lipophilic cations originally developed for myocardial perfusion SPECT imaging were identified as a class of compounds which accumulate in tumor cells due to the increased negative mitochondrial potentials and that act as substrates for Pgp and MRP $1^{[5]}$. ${ }^{99 m}$ Tc-Sestamibi was the first radiopharmaceutical recognized as a useful probe for cancer early detection and functional Pgp imaging transport ${ }^{[9]}$, followed by other ${ }^{99 \mathrm{~m}} \mathrm{Tc}$ complexes, namely ${ }^{99 \mathrm{~m}} \mathrm{Tc}$-tetrofosmin ${ }^{[10]},{ }^{99 \mathrm{~m}} \mathrm{Tc}$-furifosmin ${ }^{[11]}$, and ${ }^{99 \mathrm{~m}} \mathrm{Tc}$-areneisonitrile ${ }^{[12]}$, and, more recently, mixed-ligand ${ }^{99 \mathrm{~m}} \mathrm{Tc}$-dithiocarbamate complexes ${ }^{[13]]}$ and a ${ }^{99 \mathrm{~m}} \mathrm{Tc}$-labeled triphenylphosphonium cation ${ }^{[14]}$.

Several studies have reported that absence or reduced uptake of ${ }^{99 \mathrm{~m}} \mathrm{Tc}$-sestamibi may serve to predict poor response to therapy in several human tumors, including lymphoma ${ }^{[15]}$, nasopharyngeal cancer ${ }^{[16]}$, thyroid cancer $^{[17]}$, lung cancer $^{[18]}$, breast cancer ${ }^{[19,20]}$, ovarian cancer $^{[21]}$, osteosarcoma ${ }^{[22]}$, and renal malignancies ${ }^{[23]}$. A meta-analysis showed that ${ }^{99 \mathrm{~m}} \mathrm{Tc}$-Sestamibi could play a significant role in the management of lung cancer as it can predict accurately which patients will respond to chemotherapy ${ }^{[6]}$. However, diagnostic and prognostic values of ${ }^{99 \mathrm{~m}} \mathrm{Tc}$-Sestamibi and ${ }^{99 \mathrm{~m}} \mathrm{Tc}$-tetrofosmin are often limited due to their high uptake in the liver, which makes it very difficult to detect small lesions in the chest and abdominal regions. Thus, there is an unmet medical need for radiotracers that are able to monitor noninvasively the MDR transport function in tumors ${ }^{[5,8,24]}$.

Based on the tricarbonyl technology and using ${ }^{99 \mathrm{~m}} \mathrm{Tc}$ organometallic complexes as a lead structure, we have searched for better performing myocardial imaging agents ${ }^{[25,26]}$ and introduced and characterized a new family of cationic lipophilic ${ }^{99 \mathrm{~m}} \mathrm{Tc}$ tricarbonyl complexes. Based on promising pre-clinical studies, two of them, ${ }^{99 \mathrm{~m}} \mathrm{Tc}$-TMEOP [tri-methoxy-tris-pyrazolyl ${ }^{-99 \mathrm{~m}} \mathrm{Tc}-(\mathrm{CO})_{3}$ ] and ${ }^{99 \mathrm{~m}} \mathrm{Tc}$-DMEOP [di-methoxy-trispyrazolyl- ${ }^{99 \mathrm{~m}} \mathrm{Tc}-(\mathrm{CO})_{3}$, were considered good myocardial SPECT imaging agents, with a more favorable biological profile than the compounds in clinical use ${ }^{[25-28]}$ [Figure 1]. ${ }^{99 m}$ Tc-TMEOP and ${ }^{99 m}$ Tc-DMEOP showed very good results in the pre-clinical studies, exhibiting a good biological profile with rapid hepatic clearance. Significantly, ${ }^{99 \mathrm{~m}} \mathrm{Tc}-\mathrm{TMEOP}$ reaches in an animal model a heart/liver ratio of 1 in about half the time of the compounds in clinical use $\left({ }^{99 \mathrm{~m}} \mathrm{Tc}\right.$-Sestamibi and ${ }^{99 \mathrm{~m}} \mathrm{Tc}$-tetrofosmin), allowing for a better image quality. The evaluation of the heart uptake mechanism of ${ }^{99 \mathrm{~m}} \mathrm{Tc}$-TMEOP showed that it is similar to that of the other reported monocationic ${ }^{99 \mathrm{~m}} \mathrm{Tc}$ cardiac agents, and is associated with its accumulation in the mitochondria ${ }^{[27]}$. We also performed in vivo studies to evaluate the effect of cyclosporine A, a Pgp inhibitor, on the biodistribution of ${ }^{99 m}$ Tc-TMEOP in rats, and observed that this treatment induced a significant decrease in the washout rate from liver, kidneys, and lungs, organs with a high Pgp expression. This led us to propose that its fast liver and kidneys clearance kinetics is mediated by Pgp. Interestingly, the liver clearance of ${ }^{99 \mathrm{~m}} \mathrm{Tc}$-TMEOP is faster than for ${ }^{99 \mathrm{~m}} \mathrm{Tc}$-sestamibi and ${ }^{99 \mathrm{~m}} \mathrm{Tc}$-tetrofosmin, thus suggesting a more efficient recognition by Pgp of ${ }^{99 m}$ Tc-TMEOP and, consequently, a potentially enhanced ability of imaging the Pgp function associated to MDR tumors.

Given the better biological profile of ${ }^{99 \mathrm{~m}} \mathrm{Tc}$-TMEOP and ${ }^{99 \mathrm{~m}} \mathrm{Tc}$-DMEOP as myocardial imaging agents compared with the compounds in use, we foresee that they could have a better performance as tumoral 
detection and MDR imaging agents. Therefore, our aim with this work was to evaluate the ability of ${ }^{99 \mathrm{~m}} \mathrm{Tc}-$ TMEOP and ${ }^{99 m}$ Tc-DMEOP to target cancer cells and to functionally assess MDR.

\section{METHODS}

\section{Synthesis of ${ }^{99 \mathrm{~m}} \mathrm{Tc}$-DMEOP and ${ }^{99 \mathrm{~m}} \mathrm{Tc}$-TMEOP}

One milliliter of a $\left.{ }^{99 \mathrm{~m}} \mathrm{Tc}\left(\mathrm{H}_{2} \mathrm{O}\right)_{3}(\mathrm{CO})_{3}\right]^{+}$solution $(\mathrm{pH} 4)$, obtained using an IsoLink ${ }^{\otimes}$ kit (Covidien, Petten, the Netherlands), ranging from 37 and $370 \mathrm{MBq}$, was added to a nitrogen purged vial containing $2.8 \mathrm{mg}$ $\left[\mathrm{Na}(\mathrm{DMEOP})_{2}\right] \mathrm{I}$ or $3.4 \mathrm{mg}$ of $\left[\mathrm{Na}(\mathrm{TMEOP})_{2}\right] \mathrm{I}$, corresponding to a ligand concentration of $2.5 \times 10^{-3} \mathrm{M}$. The solution was heated to $100{ }^{\circ} \mathrm{C}$ for $30 \mathrm{~min}$. After cooling, the $\mathrm{pH}$ was adjusted to 7.4 using $0.1 \mathrm{M} \mathrm{NaOH}$. ${ }^{99 \mathrm{~m}} \mathrm{Tc}-\mathrm{DMEOP}$ and ${ }^{99 \mathrm{~m}} \mathrm{Tc}$-TMEOP were analyzed by reverse-phase high performance liquid chromatography (RP-HPLC) using a Nucleosil C18 column $(10 \mathrm{~mm}, 250 \mathrm{~mm} \times 4 \mathrm{~mm})$ and a gradient of $0.1 \%$ trifluoroacetic acid and $\mathrm{CH}_{3} \mathrm{CN}$ at a flow rate of $1 \mathrm{~mL} / \mathrm{min}$. ${ }^{99 \mathrm{~m}} \mathrm{Tc}$-sestamibi (Cardiolite, Bristol-Myers-Squibb) and ${ }^{99 \mathrm{~m}} \mathrm{Tc}-$ tetrofosmin (Myoview, GE Healthcare) were prepared according to the manufacturer's instructions.

\section{Cell lines}

A panel of human tumoral cell lines was used: A2780 ovarian carcinoma (ECACC 93112519), A431 squamous vulvar carcinoma (ECACC 85090402), Hela cervix epitheloid carcinoma (ECACC 93021013), MDA MB 231 metastatic breast adenocarcinoma (ECACC 92020424), MCF7 metastatic breast adenocarcinoma (ECACC 86012803), H69 small cell lung carcinoma (ECACC 91091802), and PC3 prostate adenocarcinoma (ECACC 90112714$)$.

In addition, the following drug-resistant variants were used: MCF7 Pgp (gift from D. Piwnica-Worms) and H69 Lx4 (ECACC 96042329), which overexpress Pgp, and H69 Ar (ATCC CRL-11351), which overexpresses MRP1. The MCF7 neo cell line (also a gift from D. Piwnica-Worms), which corresponds to MCF7 cells transfected with an empty vector, was used as a transfection control for MCF7 Pgp.

A431, Hela, MCF7, and MDA MB231 were cultured in Dulbecco's Modified Eagle Medium (DMEM) with 10\% fetal bovine serum (FBS), while A2780, H69, and PC3 were cultured in RPMI with 10\% FBS (all from Gibco Life Technologies). MCF7 Pgp and MCF7 neo grew in DMEM with 10\% FBS supplemented with $1 \mathrm{mg} / \mathrm{mL}$ of G418 (Sigma) and H69 Lx4 in RPMI with $10 \%$ FBS supplemented with $0.4 \mathrm{mg} / \mathrm{mL}$ of doxorubicin (Sigma). H69 AR were grown in RPMI with $20 \%$ FBS. Cells were cultured at $37^{\circ} \mathrm{C}$ in a humidified atmosphere with $5 \% \mathrm{CO}_{2}$ and regularly checked for mycoplasma contamination.

\section{Cell uptake and efflux studies}

For the uptake studies, cells were cultured at a density of $2 \times 10^{5}$ cells/well in 24 -well plates. After $24 \mathrm{~h}$, cells were incubated with medium containing either ${ }^{99 \mathrm{~m}} \mathrm{Tc}$-DMEOP or ${ }^{99 \mathrm{~m}} \mathrm{Tc}$-TMEOP at $\approx 37 \mathrm{kBq} / \mathrm{mL}$. At selected time points, the incubation was stopped by washing twice with ice-cold phosphate buffer saline (PBS) solution and the cells were lysed with $\mathrm{NaOH} 1 \mathrm{M}$. The radioactivity in the total cellular extracts was measured using a gamma counter (LB 2111, Berthold) and is reported as proportion to the total applied radioactivity and normalized to $1 \times 10^{6}$ cells. Each experiment was performed with four replicates and data are presented as average \pm SEM of typically $3-4$ independent experiments.

For efflux studies, the cells were incubated with the ${ }^{99 \mathrm{~m}} \mathrm{Tc}$-complexes at $37^{\circ} \mathrm{C}$ for $1 \mathrm{~h}$. Thereafter, incubation was stopped, the growth medium removed, the cells washed with PBS, and fresh medium added. The radioactivity released at different time points after incubation was measured on a gamma counter as above, and is reported as proportion to the total radioactivity taken up by the cells after $1 \mathrm{~h}$ of incubation. Each experiment was performed with four technical replicates and data are presented as average \pm SEM of typically three independent experiments (biological replicates). 


\section{Modulation studies}

For studies involving the modulation of plasma membrane potential, cells were incubated with ${ }^{99 \mathrm{~m}} \mathrm{Tc}$ DMEOP or ${ }^{99 \mathrm{~m}}$ Tc-TMEOP in a modified Earle's medium $\left(145 \mathrm{mM} \mathrm{NaCl}, 5.4 \mathrm{mM} \mathrm{KCl}, 1.2 \mathrm{mM} \mathrm{CaCl}_{2}, 0.8 \mathrm{mM}\right.$ $\mathrm{MgSO}_{4}, 0.8 \mathrm{mM} \mathrm{NaH}_{2} \mathrm{PO}_{4}, 5.6 \mathrm{mM}$ dextrose, 4.0 HEPES, and 1\% FBS, pH 7.4 \pm 0.1 ) or high $\mathrm{K}^{+}$variants prepared by equimolar substitution of $\mathrm{NaCl}$ by potassium aspartate (to 60 and $120 \mathrm{mM}$, respectively). Additionally, a medium with high $\mathrm{K}^{+}$concentration supplemented with valinomycin $(1 \mu \mathrm{g} / \mathrm{mL})$ was also tested. After $1 \mathrm{~h}$ of incubation, cell lysis was performed as described above. For mitochondrial membrane potential modulation, cells were incubated in normal culture medium with ${ }^{99 \mathrm{~m}} \mathrm{Tc}-\mathrm{DMEOP}$ or ${ }^{99 \mathrm{~m}} \mathrm{Tc}-\mathrm{TMEOP}$ in presence of Nigericin $(5 \mu \mathrm{g} / \mathrm{mL})$ and carbonylcyanide m-chlorophenylhydrazone (CCCP) $(5 \mu \mathrm{M}$ and $10 \mu \mathrm{M})$.

\section{Animal studies}

The experiments were performed with female nude mice (BALBC nu/nu) at eight weeks of age (Charles River laboratories, CRIFFA, France). The animals were housed in a temperature- and humidity-controlled room with a $12 \mathrm{~h}$ light/12 h dark schedule. Furthermore, animals were kept in filter top cages, handled in laminar flow hoods, and maintained on sterilized diet and water ad libitum. All animal experiments were performed in compliance with Portuguese regulations for animal ethics and care.

\section{Xenograft models}

Cancer cells in serum-free media at a concentration with the desired inoculum $\left(0.8-1 \times 10^{7}\right.$ cells) contained in $150 \mathrm{~L}$ were subcutaneously injected into the super scapular region of a group of nude mice. Only cell suspensions with viability greater than $95 \%$ were used. Mice were examined, weighed, and their tumors measured every two days. Tumors reached an appropriate size after approximately 2-4 weeks.

\section{Biodistribution}

Animals were intravenously injected into the tail vein with $100 \mu \mathrm{L}$ of a solution of ${ }^{99 \mathrm{~m}} \mathrm{Tc}$-TMEOP (0.5-1 MBq) in PBS pH 7.2 and were sacrificed by excess anesthesia at 1 and $4 \mathrm{~h}$ after injection. The injected activity (IA) was assumed to be the difference between the measured radioactivity in a dose calibrator (Curiemeter IGC-3, Aloka, Tokyo, Japan) in the syringe before and after injection. The organs of interest were dissected, rinsed with saline to remove excess blood, weighed, and their radioactivity was measured using a gammacounter (LB2111, Berthold, Germany). The uptake in the tissues of interest was calculated and expressed as a percentage of the injected radioactivity per gram of tissue (\% IA/g). For blood, bone, and muscle, total activity was estimated assuming that these organs constitute $6 \%, 10 \%$, and $40 \%$ of the total body weight, respectively. Statistical analysis of the data ( $t$-test) was done with GraphPad Prism and the level of significance was set as 0.05 .

\section{Western blot}

Cells were lysed in Cell Lytic-MT Extraction reagent (Sigma) supplemented with Complete protease inhibitor cocktail tablets (Roche Applied Science). After $15 \mathrm{~min}$ on ice, lysates were centrifuged at 14,000 $\mathrm{g}$ for $10 \mathrm{~min}$ at $4{ }^{\circ} \mathrm{C}$ to pellet the cellular debris and the supernatants were removed for further use. The total protein content was determined by using the DC Protein Assay Kit (Biorad) and aliquots of protein $(100 \mu \mathrm{g})$ from each sample were analyzed using standard Western blot procedures. Briefly, protein extracts were subjected to electrophoresis on a $7 \%$ sodium dodecyl sulfate-polyacrylamide gel and transferred electrophoretically onto nitrocellulose membranes. The blots were blocked with PBS-tween (PBS-T) containing 5\% nonfat dry milk for $1 \mathrm{~h}$. Then, the blotting membranes were incubated with primary antibodies against Pgp (1:1000, Abcam), MRP1 (1:500, Abcam), and actin (1:8000, Sigma) overnight. Membranes were washed with PBS-T and incubated for $1 \mathrm{~h}$ with secondary antibody (goat anti-mouse IgGHRP, Biorad) diluted 1:3000. Finally, membranes were developed using the SuperSignal WestPico Substrate kit (Pierce, Rockford, IL) according to the manufacturer's instructions. Samples of the xenotransplants were excised and mechanically fragmented. Then, the samples were lysed and processed as described above. 

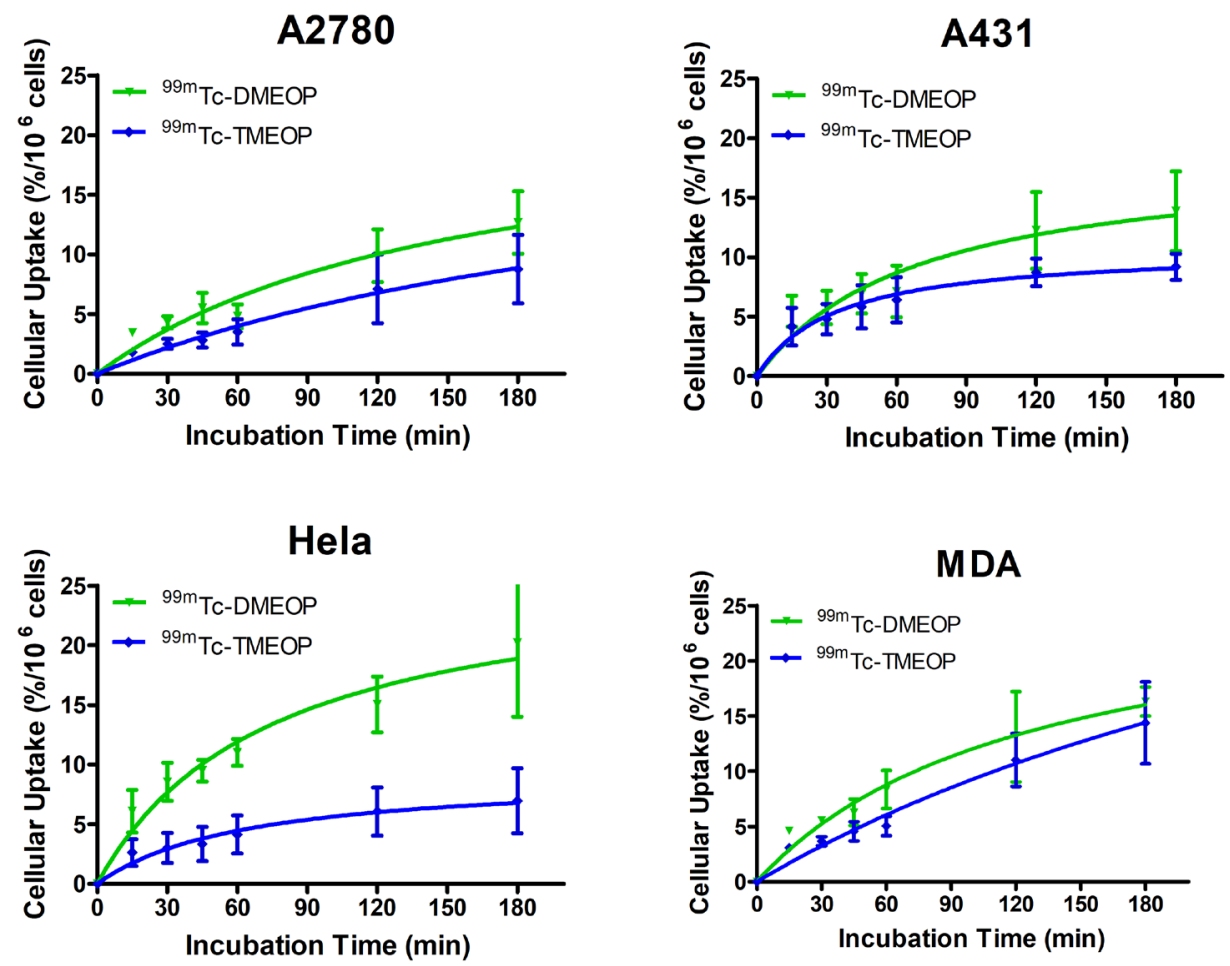

Figure 2. Cellular uptake of ${ }^{99 \mathrm{~m}} \mathrm{Tc}-\mathrm{DMEOP}$ and ${ }^{99 \mathrm{~m}} \mathrm{Tc}-\mathrm{TMEOP}$ in several human cancer cell lines, represented as the percentage of cellassociated radioactivity normalized to $10^{6}$ cells over time. The results presented were calculated from independent biological replicates $(n$ $=3$ ) and are given as the average \pm SEM

\section{RESULTS}

As previously reported, the cationic lipophilic complexes ${ }^{99 \mathrm{~m}} \mathrm{Tc}$-DMEOP and ${ }^{99 \mathrm{~m}} \mathrm{Tc}$-TMEOP could be obtained in quantitative yield and with high radiochemical purity ( $>99 \%)$, being used in the biological studies reported herein without any purification ${ }^{[26]}$.

\section{In vitro evaluation of tumoral detection}

Uptake in tumoral cells

Cellular uptake assays were firstly conducted to evaluate the ability of the two radiocomplexes to enter into tumoral cells. A panel of cellular models from different types of human tumors was used, in order to get an insight into the biological selectivity of the complexes, and, afterwards, for some selected cases, a comparison with radiopharmaceuticals in clinical use, ${ }^{99 m} \mathrm{Tc}$-Sestamibi and ${ }^{99 \mathrm{~m}} \mathrm{Tc}$-tetrofosmin, was also performed. Figure 2 presents the results for the uptake kinetics in ovarian A2780, vulvar A431, cervix Hela and breast MDA MB231 carcinoma cell lines. The results show that cellular uptake increased as a function of incubation time for all tumoral cell lines, with ${ }^{99 m} \mathrm{Tc}$-DMEOP generally presenting higher uptake values than ${ }^{99 \mathrm{~m}}$ Tc-TMEOP. After $3 \mathrm{~h}$ of incubation, Hela cells exhibited the highest uptake of ${ }^{99 \mathrm{~m}} \mathrm{Tc}$-DMEOP (with almost $20 \%$ of applied activity associated with the cells), followed by MDA MB231 (with almost 18\%) and then A2780 and A431 with similar values (between 12\% and 13\%). In Hela, A2780, and A431 cell lines, ${ }^{99 \mathrm{~m}} \mathrm{Tc}$-TMEOP presented uptake values around $10 \%(7 \%, 8 \%$, and $9 \%$ of applied activity associated with the cells, respectively) and, in MDA MB231 cell line, the uptake value was more similar to the one presented by ${ }^{99 m}$ Tc-DMEOP (14\% and $18 \%$, respectively).

Next, we evaluated the uptake of our two radiocomplexes in comparison with the radiopharmaceuticals in clinical use, ${ }^{99 \mathrm{~m}} \mathrm{Tc}$-Sestamibi and ${ }^{99 \mathrm{~m}} \mathrm{Tc}$-tetrofosmin, which have been shown to accumulate in tumoral cells in vitro and in vivo. For this study, we considered the MCF7, H69, and PC3 cancer cell lines [Figure 3]. 

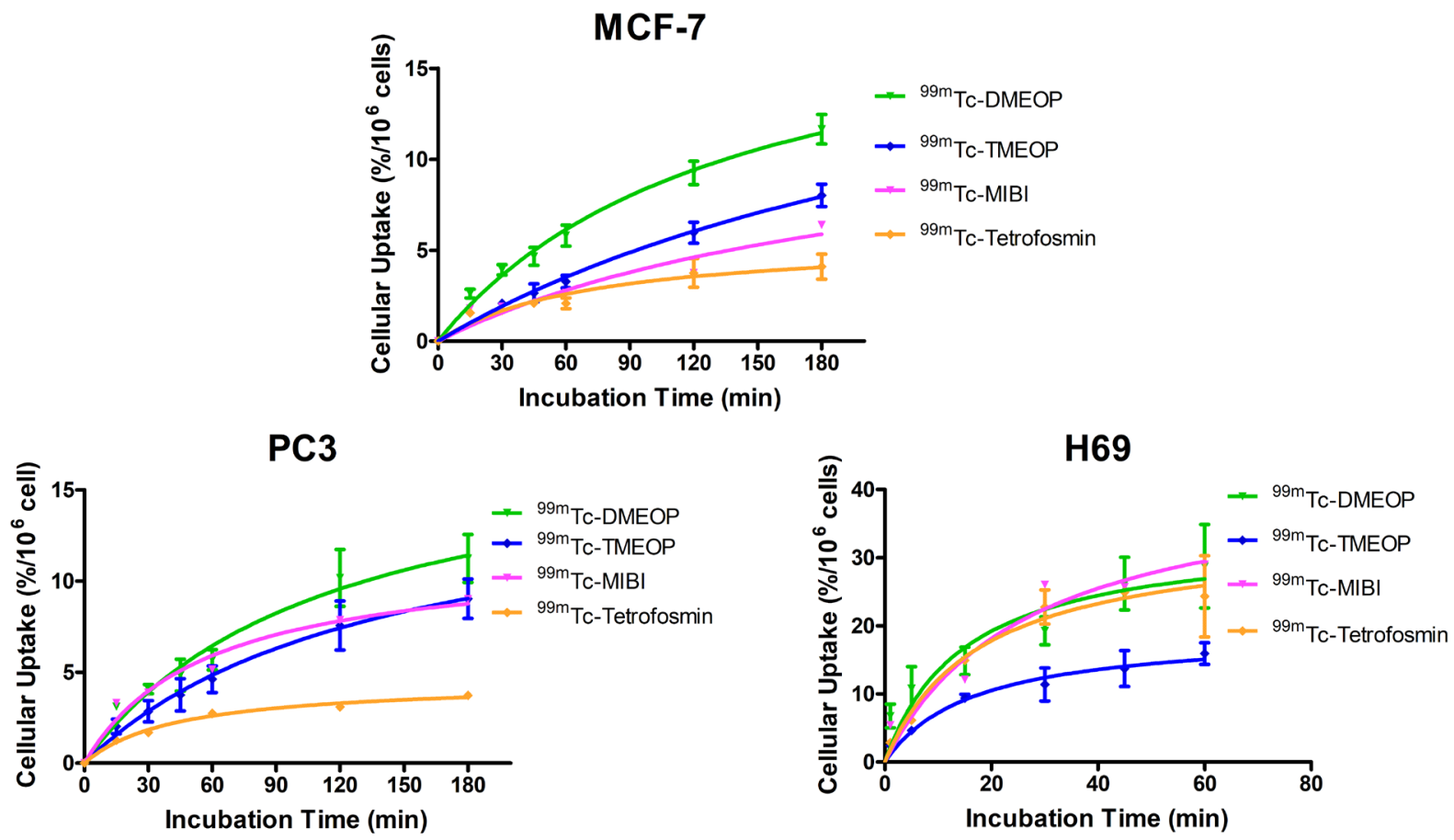

Figure 3. Cellular uptake of ${ }^{99 \mathrm{~m}} \mathrm{Tc}-\mathrm{DMEOP},{ }^{99 \mathrm{~m}} \mathrm{Tc}-\mathrm{TMEOP},{ }^{99 \mathrm{~m}} \mathrm{Tc}-\mathrm{Sestamibi}$, and ${ }^{99 \mathrm{~m}} \mathrm{Tc}$-tetrofosmin in several human cancer cell lines, represented as the percentage of cell-associated radioactivity normalized to $10^{6}$ cells over time. The results presented were calculated from independent biological replicates $(n=3-8)$ and are given as the average \pm SEM

We selected these cell lines because breast, lung, and prostate cancers are among the ones that more often develop resistance to treatment as well as present high metastatic potential.

In the breast cancer cell line MCF7 and in the prostate cancer cell line PC3, ${ }^{99 \mathrm{~m}} \mathrm{Tc}$-DMEOP and ${ }^{99 \mathrm{~m}} \mathrm{Tc}$ TMEOP presented a moderate uptake with values between $8 \%$ and $9 \%$ at $3 \mathrm{~h}$ for ${ }^{99 \mathrm{~m}} \mathrm{Tc}$-TMEOP and slightly above $11 \%-12 \%$ at the same time point for ${ }^{99 \mathrm{~m}} \mathrm{Tc}$-DMEOP. In these cell lines, ${ }^{99 \mathrm{~m}} \mathrm{Tc}-\mathrm{MIBI}$ behaved similarly to ${ }^{99 \mathrm{~m}} \mathrm{Tc}$-DMEOP. This is in contrast with ${ }^{99 \mathrm{~m}} \mathrm{Tc}$-tetrofosmin, which presents the lowest uptake values (3\% and $4 \%$ at $3 \mathrm{~h}$ for PC3 and MCF7, respectively). The small cell lung cancer $\mathrm{H} 69$ presented in general higher uptake values. This can be explained by the fact that, since it is a suspension cell line, the cell membrane area in contact with the radioactive medium is increased when compared with adherent monolayers. In this cell line, ${ }^{99 \mathrm{~m}} \mathrm{Tc}$-DMEOP, ${ }^{99 \mathrm{~m}} \mathrm{Tc}$-Sestamibi, and ${ }^{99 \mathrm{~m}} \mathrm{Tc}$-tetrofosmin presented similar kinetics and uptake values at $1 \mathrm{~h}$ (28\% of cell associated activity for ${ }^{99 \mathrm{~m}} \mathrm{Tc}-\mathrm{DMEOP}$ and ${ }^{99 \mathrm{~m}} \mathrm{Tc}$-Sestamibi and $24 \%$ for ${ }^{99 \mathrm{~m}} \mathrm{Tc}$-tetrofosmin), with ${ }^{99 \mathrm{~m}} \mathrm{Tc}$-TMEOP reaching values of $\sim 60 \%$ of the uptake of the other compounds.

To examine if ${ }^{99 \mathrm{~m}} \mathrm{Tc}$-DMEOP, ${ }^{99 \mathrm{~m}} \mathrm{Tc}$-TMEOP, and ${ }^{99 \mathrm{~m}} \mathrm{Tc}$-Sestamibi might also exhibit similar profiles of intracellular retention in the adherent MCF7 and PC3 tumoral cell lines, we performed efflux experiments. The results obtained for the kinetics of efflux, after a loading incubation of $1 \mathrm{~h}$, are presented in Figure 4 . We observed a continuous and moderate washout for the three radiocomplexes throughout time in the two cell lines. For the PC3 cell line, ${ }^{99 m}$ Tc-Sestamibi presented a slightly less pronounced efflux.

\section{Mechanism of cellular uptake}

In our initial characterization of the mechanism of myocardial uptake and subcellular localization of ${ }^{99 m}$ Tc-TMEOP, we showed that this uptake is influenced by both the lipophilicity and the charge ${ }^{[27]}$. As hypothesized for other radiotracers ${ }^{[29]}$, the lipophilicity modulates the entry into the cellular and mitochondrial membranes, while the negative mitochondrial potential provides the electrochemical driving force for the radiotracers to localize in the myocyte's mitochondrial compartments. in vivo, ${ }^{99 \mathrm{~m}} \mathrm{Tc}-\mathrm{TMEOP}$ 
PC3

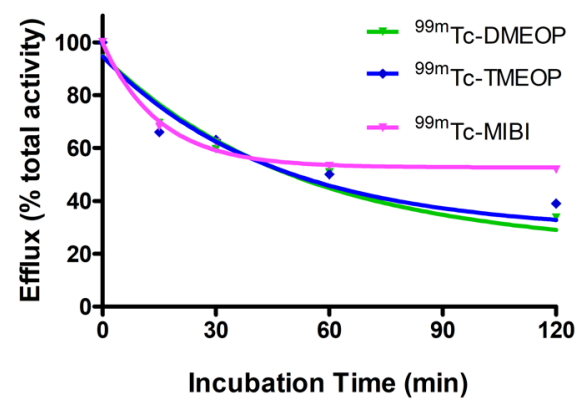

MCF7

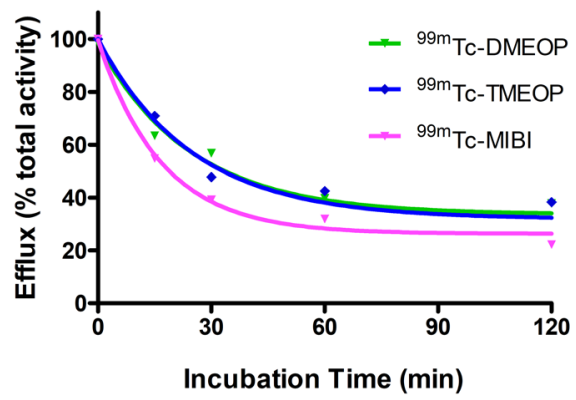

Figure 4. Cellular efflux of ${ }^{99 \mathrm{~m}} \mathrm{Tc}-\mathrm{DMEOP}$, ${ }^{99 \mathrm{~m}} \mathrm{Tc}-\mathrm{TMEOP}$, and ${ }^{99 \mathrm{~m}} \mathrm{Tc}-$ Sestamibi in several human cancer cell lines, represented as the percentage of cellular retention over a period of $2 \mathrm{~h}$. The results presented were calculated from independent biological replicates $(n=3)$ and are given as the average \pm SEM

(and ${ }^{99 \mathrm{~m}} \mathrm{Tc}$-DMEOP) tends to localize into the heart tissue where there is an increased mitochondrial population compared to other tissues. In most tumoral cells, the negative mitochondrial potential is greatly enhanced (approximately - $220 \mathrm{mV}$ in cancer cells compared to approximately - $140 \mathrm{mV}$ in normal cells) ${ }^{[30,31]}$, and therefore we tested if this could be the driving force for the uptake of our radiocomplexes in tumoral cells. To establish the influence of the plasma membrane potential $(\Delta \psi \mathrm{p})$ and mitochondrial membrane potential $(\Delta \psi \mathrm{m})$ on the uptake of these two radiocomplexes, MCF7 cells were incubated in different conditions that promoted the alteration or collapse of $\Delta \psi \mathrm{p}$ and/or $\Delta \psi \mathrm{m}$.

$\Delta \psi \mathrm{p}$ is generated mainly by the movement of $\mathrm{K}^{+}$ions from inside to outside the cell through $\mathrm{K}^{+}$ channels ${ }^{[32,33]}$. Therefore, to modulate the $\Delta \psi \mathrm{p}$, experiments were performed in the presence of a buffer solution with increasing concentrations of $\mathrm{K}^{+}(5,60$, and $120 \mathrm{mM})$. The increase in $\mathrm{K}^{+}$concentration in the medium from the physiological $5 \mathrm{mM}$ to near $120 \mathrm{mM}$ establishes an equilibrium between the extracellular and intracellular concentration of this ion, and as a direct consequence to depolarization of the plasma membrane. Under these experimental conditions, there is no expected influence of the $\Delta \psi p$ in the cellular uptake of the radiotracers and their uptake can be exclusively related to $\Delta \psi \mathrm{m}$. MCF7 cells were incubated in 5,60 , and $120 \mathrm{mM} \mathrm{K}{ }^{+}$modified media in the presence of ${ }^{99 \mathrm{~m}} \mathrm{Tc}$-DMEOP and ${ }^{99 \mathrm{~m}} \mathrm{Tc}$-TMEOP for $1 \mathrm{~h}$. Moreover, an additional incubation with $120 \mathrm{mM} \mathrm{K}^{+}$modified media in presence of valinomycin was also performed. Valinomycin is a potassium ionophore that increases membrane permeability to $\mathrm{K}^{+}$. Since $\Delta \psi \mathrm{p}$ is nearly zero for high extracellular concentrations of $\mathrm{K}^{+}$, the addition of valinomycin can lead to the collapse of $\Delta \psi \mathrm{m}$ due to the uncoupling of electron chain in oxidative phosphorylation ${ }^{[30]}$. The results of these experiments are presented in Figure 5A.

Modulation of $\Delta \psi \mathrm{p}$ through increasing extracellular $\mathrm{K}^{+}$concentration did not affect the uptake of either compound, as the values obtained for each experimental condition are similar. On the other hand, upon the collapse of $\Delta \psi \mathrm{m}$ with valinomycin, there was a marked reduction of $50 \%$ on the cellular uptake of both ${ }^{99 \mathrm{~m}} \mathrm{Tc}$-DMEOP and ${ }^{99 \mathrm{~m}} \mathrm{Tc}$-TMEOP, confirming that $\Delta \psi \mathrm{m}$ is a critical factor for the intracellular accumulation of these compounds. To further investigate the roles of $\Delta \psi \mathrm{p}$ and $\Delta \psi \mathrm{m}$ in the uptake of ${ }^{99 \mathrm{~m}} \mathrm{Tc}-$ DMEOP and ${ }^{99 \mathrm{~m}} \mathrm{Tc}-\mathrm{TMEOP}$, incubations were performed in the presence of another set of ionophores: nigericin and CCCP. Nigericin mediates the electroneutral substitution of $\mathrm{H}^{+}$for $\mathrm{K}^{+}$, in effect collapsing the $\mathrm{pH}$ gradient of the inner mitochondrial membrane with its subsequent hyperpolarization ${ }^{[34]}$. CCCP is a well known protonophore. It mediates the diffusion of $\mathrm{H}^{+}$through the membranes and, as such, promotes the decoupling of $\mathrm{pH}$ gradient across the inner mitochondrial membrane, effectively collapsing $\Delta \psi \mathrm{m}$ selectively ${ }^{[35]}$. Upon MCF7 incubation in the presence of these compounds for $1 \mathrm{~h}$, nigericin produced a $37 \%$ increase in the uptake for both ${ }^{99 \mathrm{~m}} \mathrm{Tc}$-DMEOP and ${ }^{99 \mathrm{~m}} \mathrm{Tc}$-TMEOP when compared with normal media [Figure $5 \mathrm{~B}]$. This result reflects, and is in accordance with, the expected hyperpolarization of the 
A

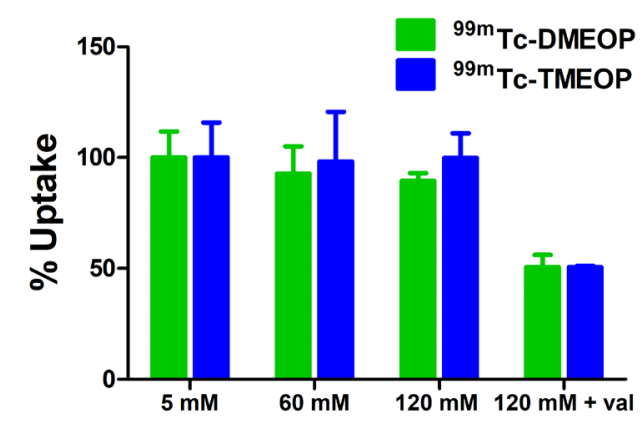

B

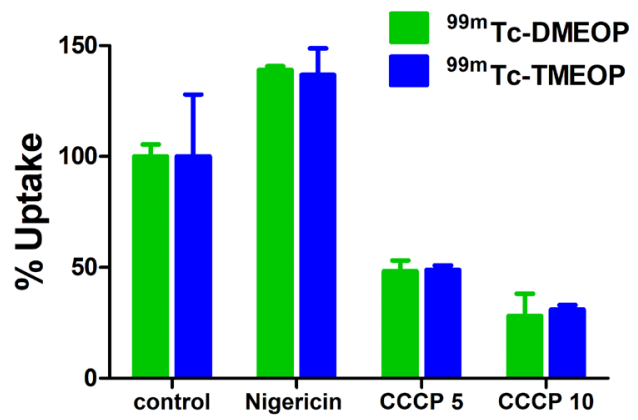

Figure 5. Cellular uptake of ${ }^{99 \mathrm{~m}} \mathrm{Tc}-\mathrm{DMEOP}$ and ${ }^{99 \mathrm{~m}} \mathrm{Tc}$-TMEOP in MCF7 cells incubated for $1 \mathrm{~h}$ with: $(\mathrm{A})$ increasing concentrations of $\mathrm{K}^{+}$and in the presence of valinomycin $(1 \mu \mathrm{g} / \mathrm{mL})$, where the results are presented as the percentage of uptake in relation to the medium with $5 \mathrm{mM}$ $\mathrm{K}^{+}$; and $(\mathrm{B})$ normal medium supplemented with nigericin $(5 \mu \mathrm{g} / \mathrm{mL})$ and CCCP (5 and $\left.10 \mu \mathrm{M}\right)$, where the results are presented as the percentage of uptake in relation to the normal medium. The results were calculated from independent biological replicates $(n=3)$ and are given as the average \pm SEM. CCCP: carbonylcyanide m-chlorophenylhydrazone

mitochondrial membrane. When cells were incubated with the radiocomplexes in the presence of CCCP, a dose-dependent reduction of uptake of $52 \%-72 \%$ for ${ }^{99 \mathrm{~m}} \mathrm{Tc}$-DMEOP and $52 \%-70 \%$ for ${ }^{99 \mathrm{~m}}$ Tc-TMEOP was observed, supporting the idea that $\Delta \psi \mathrm{m}$ is indeed the determinant driving force for the intracellular diffusion of these complexes.

\section{In vitro monitoring of multidrug resistance}

After the evaluation of the performance of ${ }^{99 \mathrm{~m}} \mathrm{Tc}$-DMEOP and ${ }^{99 \mathrm{~m}} \mathrm{Tc}$-TMEOP for tumoral detection, the next step was the characterization of their ability to functionally assess MDR. We selected drug-resistant variants of the previously tested MCF7 breast and H69 lung cancer cell lines: MCF7 Pgp and H69 Lx4, which overexpress Pgp, and H69 AR, which overexpresses MRP1. We could confirm by Western blot the expression of these transporters in the cell lines selected, as well as their absence from the drug-sensitive cell lines [Figure 6].

The uptake kinetics of ${ }^{99 \mathrm{~m}} \mathrm{Tc}$-DMEOP and ${ }^{99 \mathrm{~m}} \mathrm{Tc}$-TMEOP in comparison with ${ }^{99 \mathrm{~m}} \mathrm{Tc}$-MIBI in the three cell lines tested are presented in Figure 7. For all compounds evaluated, the uptake in the drug resistant cell lines was greatly reduced when compared with the uptake in the non-resistant lines, which is plotted for comparison. For the MCF7 Pgp cell line, the values of uptake after $3 \mathrm{~h}$ incubation decreased 3.2 times for ${ }^{99 \mathrm{~m}} \mathrm{Tc}$-DMEOP and ${ }^{99 \mathrm{~m}} \mathrm{Tc}-\mathrm{MIBI}$ in comparison with MCF7 (from $12 \%$ to $3.7 \%$ and from $6.4 \%$ to $2 \%$ for ${ }^{99 \mathrm{~m}} \mathrm{Tc}-\mathrm{DMEOP}$ and ${ }^{99 \mathrm{~m}} \mathrm{Tc}-\mathrm{MIBI}$, respectively), and almost 4.5 times for ${ }^{99 \mathrm{~m}}$ Tc-TMEOP (from $8 \%-9 \%$ to $2 \%$ ).

For the small cell lung carcinoma cell lines, a similar trend was observed: a reduction of the uptake values in the Pgp-overexpressing cell line H69 Lx4 compared with H69. The greatest reduction was observed for ${ }^{99 \mathrm{~m}} \mathrm{Tc}$-TMEOP, which presents uptake values at $1 \mathrm{~h}$ more than 13 times inferior in the drug-resistant cells (from $15.9 \%$ to $1.2 \%$ ). For ${ }^{99 \mathrm{~m}} \mathrm{Tc}-\mathrm{MIBI}$, the reduction of uptake in relation to the non-resistant $\mathrm{H} 69$ cell line was $\sim 11$ times (from $29 \%$ to $2.6 \%$ at $1 \mathrm{~h}$ ) and for ${ }^{99 \mathrm{~m}} \mathrm{Tc}$-DMEOP $\sim 5$ times (from $28.7 \%$ to $5.5 \%$ at $1 \mathrm{~h}$ ). Interestingly, in the derivative line overexpressing MRP1, H69AR, the uptake of ${ }^{99 \mathrm{~m}} \mathrm{Tc}$-TMEOP (and ${ }^{99 \mathrm{~m}} \mathrm{Tc}$ MIBI) was almost null, being drastically reduced compared with the parental H69. This seems to suggest that this complex functions as a substrate of both Pgp and MRP1.

These results suggest that ${ }^{99 \mathrm{~m}} \mathrm{Tc}$-TMEOP, despite having a slightly lower uptake in the cancer tumoral cells when compared with ${ }^{99 \mathrm{~m}} \mathrm{Tc}$-DMEOP and in some cases with ${ }^{99 \mathrm{~m}} \mathrm{Tc}$-MIBI (see Figure 3), presents the advantage of having more reduced uptake in the drug-resistant cell lines. ${ }^{99 m}$ Tc-TMEOP is, from our two radiocomplexes studied, the one with the best ability to detect the MDR phenotype, as it seems to be a better substrate for Pgp and MRP1 than ${ }^{99 \mathrm{~m}} \mathrm{Tc}-\mathrm{DMEOP}$. 


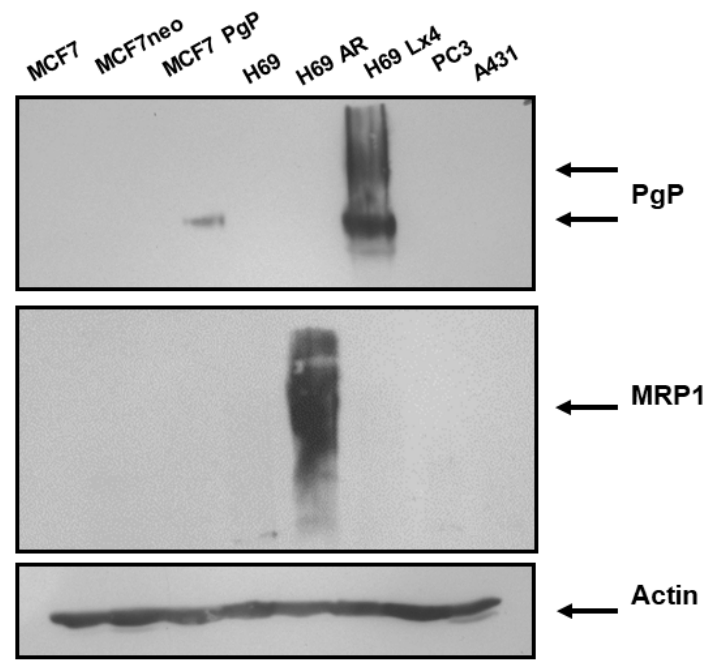

Figure 6. Expression of multidrug resistance proteins in human cancer cell lines. Western blot analysis was used to examine the protein expression levels of Pgp and MRP1. Actin was used as a loading control. MCF7 neo cells are a transfection control for MCF7 Pgp. Pgp: P-glycoprotein; MRP1: multidrug-resistant protein 1
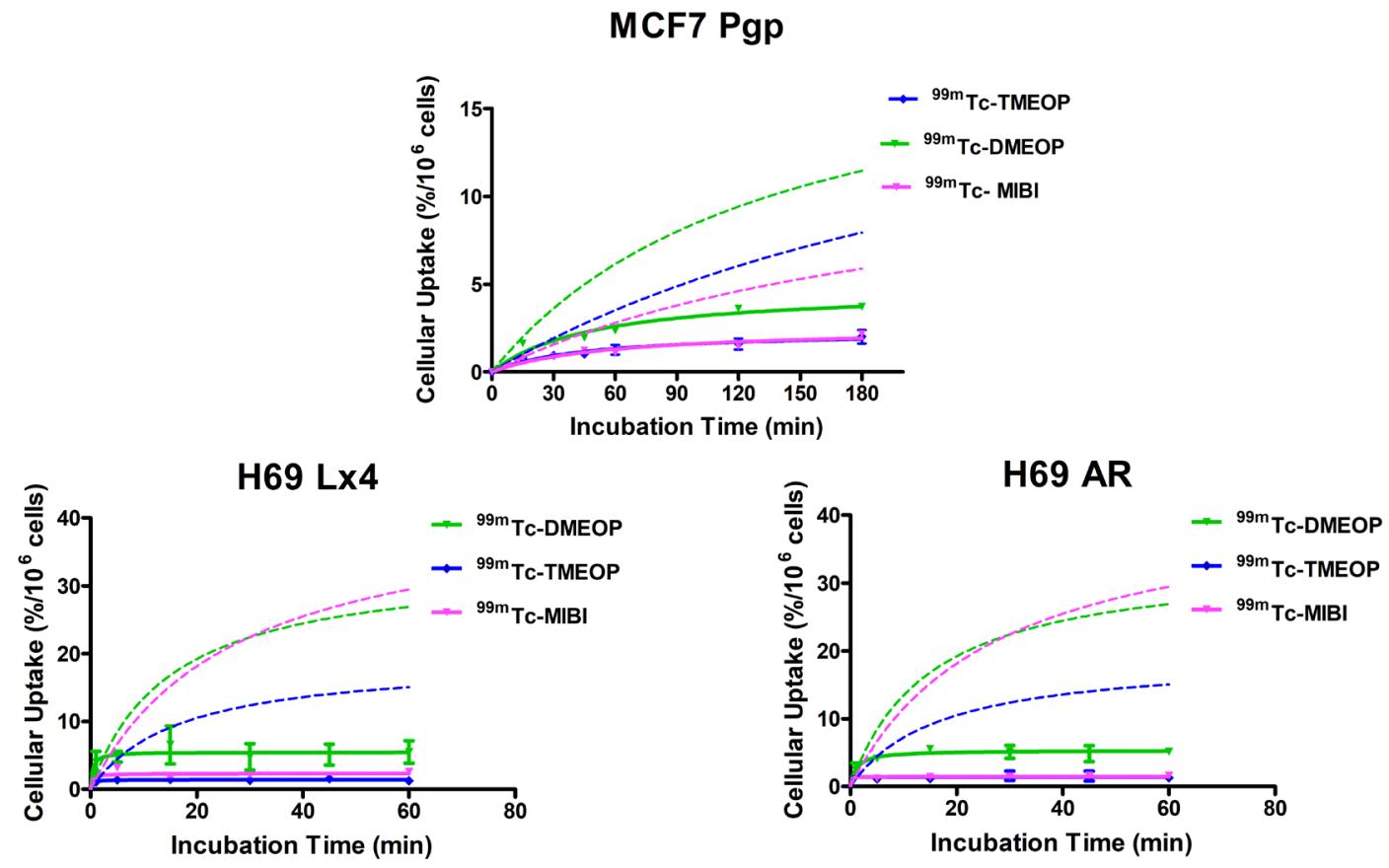

Figure 7. Cellular uptake of ${ }^{99 \mathrm{~m}} \mathrm{Tc}-\mathrm{DMEOP},{ }^{99 \mathrm{~m}} \mathrm{Tc}-\mathrm{TMEOP}$, and ${ }^{99 \mathrm{~m}} \mathrm{Tc}$-Sestamibi in several human drug resistant cancer cell lines: MCF7 Pgp and H69 Lx4 overexpressing the Pgp protein and H69 AR overexpressing MRP1. For comparison, the uptake curves in the corresponding non-resistant cell lines, MCF7 and H69 (discontinuous lines), are also represented. The results are presented as the percentage of cellassociated radioactivity normalized to $10^{6}$ cells over time, were calculated from independent biological replicates $(n=3-4)$, and are given as the average \pm SEM. Pgp: P-glycoprotein; MRP1: multidrug-resistant protein 1

\section{Effect of a MDR modulator}

Based on the promising uptake results in the drug-resistant cell lines, and to confirm if the lower uptake in these resistant cell lines could be attributed to the overexpression of $\mathrm{ABC}$ transporters, we next studied the uptake of ${ }^{99 \mathrm{~m}} \mathrm{Tc}$-TMEOP in the H69 Lx4 resistant cells in the presence of verapamil, a modulator of Pgp. To select the best concentration range of verapamil, a first screening was done using different concentrations at $1 \mathrm{~h}$ of incubation [Figure $8 \mathrm{~A}$ ]. 
A

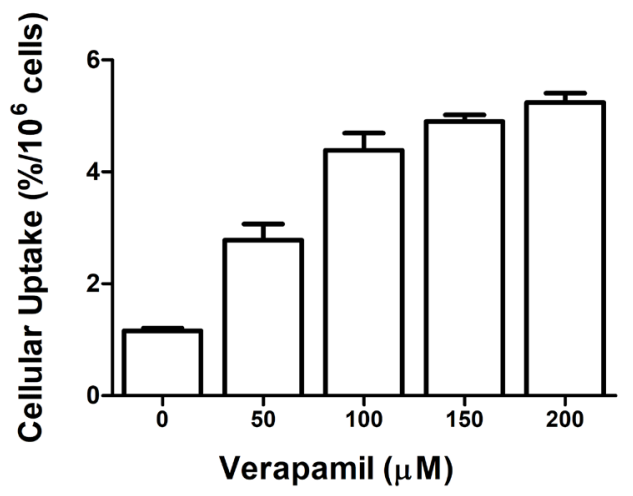

B

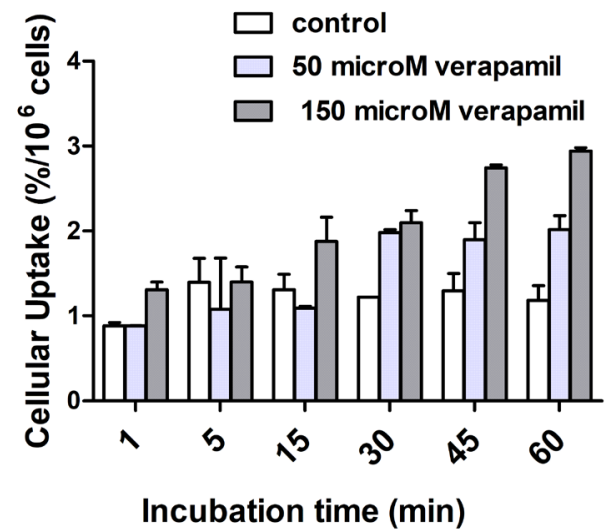

Figure 8. Cellular uptake of ${ }^{99 \mathrm{~m}} \mathrm{Tc}-\mathrm{TMEOP}$ in $\mathrm{H} 69 \mathrm{Lx} 4$ cells in the presence of a Pgp modulator: (A) uptake at $1 \mathrm{~h}$ after incubation with increasing concentrations of verapamil; and (B) uptake over time after incubation with 50 and $150 \mathrm{M}$ of verapamil. The results are presented as the percentage of cell-associated radioactivity normalized to $10^{6}$ cells, were calculated from independent biological replicates $(n=2)$, and are given as the average \pm SEM. Pgp: P-glycoprotein

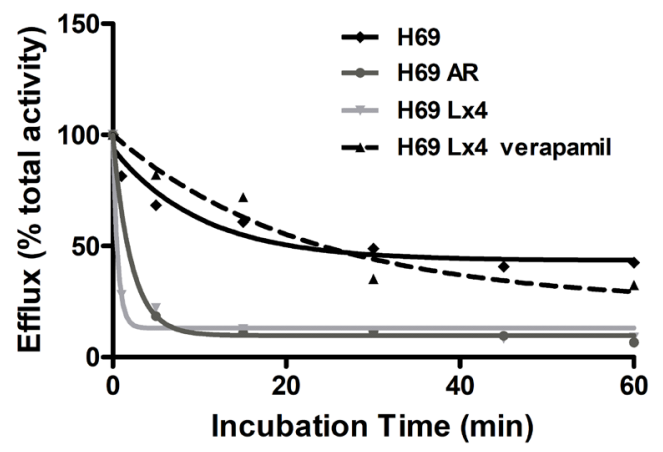

Figure 9. Cellular efflux of ${ }^{99 \mathrm{~m}} \mathrm{Tc}-\mathrm{TMEOP}$ in $\mathrm{H} 69$ and drug-resistant variants H69 Lx4 and H69 AR and in H69 Lx4 incubated with $150 \mathrm{M}$ of verapamil, presented as the percentage of cellular retention over a period of $1 \mathrm{~h}$. The results presented were calculated from independent biological replicates $(n=2)$

As can be seen in Figure 8A, there is a concentration-dependent increase of the cell uptake, compared to the control. We then selected 50 and $150 \mathrm{mM}$ of verapamil to perform a time-dependent uptake assay [Figure 8B], which showed a time-dependent uptake of ${ }^{99 \mathrm{~m}} \mathrm{Tc}$-TMEOP in the modulator-treated cells, in clear contrast with the non-treated cells. Additionally, we performed efflux studies in the presence of verapamil, as presented in Figure 9. The efflux of ${ }^{99 m}$ Tc-TMEOP in H69 Lx4 and H69 AR is fast, with only 20\% of the radiocomplexes remaining in the cells at the 5-min time point. In the parental line, H69, which does not overexpress Pgp or MRP1, the efflux is lower and at a slower rate, with $\sim 68 \%$ of intracellular ${ }^{99 \mathrm{~m}} \mathrm{Tc}$-TMEOP at $5 \mathrm{~min}$. Interestingly, when $\mathrm{H} 69 \mathrm{Lx} 4$ cells were incubated with verapamil, there was a clear reduction of the efflux of ${ }^{99 m} \mathrm{Tc}$-TMEOP, to levels similar to the ones presented in $\mathrm{H} 69$ cells.

Taken together, the results of uptake and efflux in cancer cell lines overexpressing MDR-relevant proteins (Pgp and MRP1) confirm the potential of ${ }^{99 \mathrm{~m}} \mathrm{Tc}$-DMEOP but more so of ${ }^{99 \mathrm{~m}} \mathrm{Tc}$-TMEOP for the functional imaging of tumoral MDR. Therefore, we decided to study the in vivo behavior of the later in animal models with human cancer xenografts. 


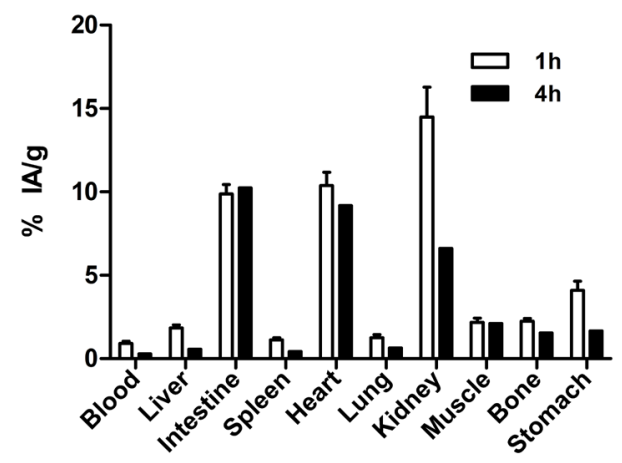

Figure 10. Biodistribution of ${ }^{99 \mathrm{~m}} \mathrm{Tc}-\mathrm{TMEOP}$ in nude mice. Mice were injected intravenously with $0.6 \mathrm{MBq}$ and sacrificed 1 and $4 \mathrm{~h}$ postinjection. The results are presented as the average \pm SEM of the percentage IA $/ g$ tissue at each time point $(n=4)$. IA: injected activity

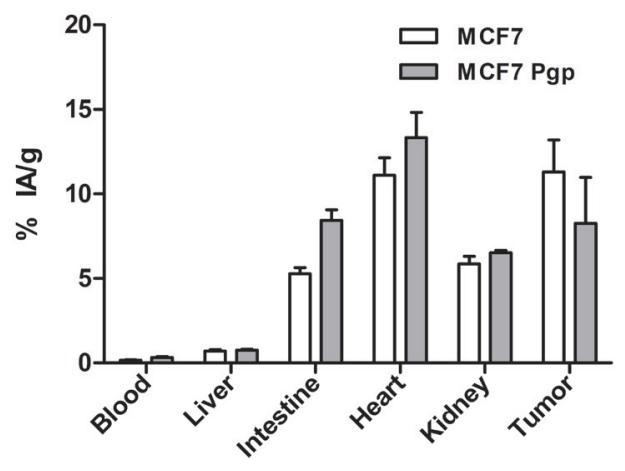

Figure 11. Biodistribution of ${ }^{99 \mathrm{~m}} \mathrm{Tc}-\mathrm{TMEOP}$ in tumor-bearing nude mice with uptake in selected organs. Mice were injected intravenously with 0.6-1 MBq, and sacrificed at $4 \mathrm{~h}$ post-injection. The results are presented as the average \pm SEM of the percentage injected activity/g tissue at each time point $(n=3-4)$. Pgp: P-glycoprotein

\section{In vivo studies}

To evaluate in vivo the ability of ${ }^{99 \mathrm{~m}} \mathrm{Tc}-\mathrm{TMEOP}$ for tumoral detection and imaging of MDR, we performed preliminary studies with nude mice with breast cancer xenografts. MCF7 and MCF7 Pgp cells were inoculated in nude mice and, when the tumor xenografts reached substantial size, biodistribution assays were carried out. Figure 10 presents the general biodistribution profile of ${ }^{99 \mathrm{~m}} \mathrm{Tc}$-TMEOP in $B A L B / c$ Nude mice, which, in accordance with our previous results, presented a high and persistent heart uptake $[\sim 10 \%$ of injected activity/g tissue (\% IA/g) at $1 \mathrm{~h}$ and $9.2 \% \mathrm{IA} / \mathrm{g}$ at $4 \mathrm{~h}$ ], with fast blood and liver clearance. A pronounced hepatobiliary excretion was found, as expected due to its lipophilic character; however, a relevant fraction was also eliminated through the kidney ( 14.5 $\mathrm{IA} / \mathrm{g}$ at $2 \mathrm{~h}$ and $6.6 \% \mathrm{IA} / \mathrm{g}$ at $4 \mathrm{~h}$ ).

In tumor-bearing nude mice, the overall biodistribution profile of ${ }^{99 \mathrm{~m}} \mathrm{Tc}$-TMEOP at $4 \mathrm{~h}$ post-injection was similar to non-tumor-bearing nude mice, as can been seen in Table 1 and Figure 11, where the uptake in the most relevant organs is presented.

In terms of tumoral uptake, an accumulation of ${ }^{99 \mathrm{~m}} \mathrm{Tc}$-TMEOP in the xenografts was observed, with MCF7 xenografts presenting a higher uptake of ${ }^{99 \mathrm{~m}} \mathrm{Tc}$-TMEOP when compared with MCF7 Pgp xenografts (although not statistically different). When considering the tumor/blood ratio, which at $4 \mathrm{~h}$ clearly showed the impact of blood clearance of the radioprobe, the animals with MCF7 xenografts presented a higher ratio than the ones with MCF7 Pgp tumors.

The biochemical characterization of the tumor xenografts was performed after the biodistribution assay, to confirm the expression of Pgp, as studies have showed that, in some situations, there is an alteration of 
Table 1. Biodistribution of ${ }^{99 \mathrm{~m}} \mathrm{Tc}-\mathrm{TMEOP}$ in tumor-bearing nude mice

\begin{tabular}{lcccc}
\hline \multirow{2}{*}{$\%$ IA/g } & \multicolumn{2}{c}{ MCF7 } & \multicolumn{2}{c}{ MCF7 Pgp } \\
\cline { 2 - 5 } & Average & SEM & Average & SEM \\
\hline Blood & 0.17 & 0.02 & 0.33 & 0.04 \\
Liver & 0.73 & 0.08 & 0.75 & 0.06 \\
Intestine & 6.21 & 0.97 & 8.44 & 0.62 \\
Spleen & 0.72 & 0.11 & 0.58 & 0.08 \\
Heart & 10.75 & 0.94 & 13.33 & 1.50 \\
Lung & 0.81 & 0.07 & 1.02 & 0.09 \\
Kidney & 5.78 & 0.38 & 6.53 & 0.12 \\
Muscle & 2.54 & 0.24 & 2.69 & 0.14 \\
Bone & 1.86 & 0.18 & 2.15 & 0.31 \\
Stomach & 1.50 & 0.27 & 2.25 & 0.16 \\
Tumor & 11.30 & 1.89 & 8.26 & 2.72 \\
Ratio tumor/blood & 100.81 & 56.21 & 27.73 & 18.03 \\
Ratio tumor/muscle & 4.06 & 0.40 & 3.19 & 1.89 \\
\hline
\end{tabular}

Mice were injected intravenously with 0.6-1 MBq and sacrificed at $4 \mathrm{~h}$ post-injection. The results are presented as the average \pm SEM of the the percentage IA $/ g$ tissue at each time point $(n=3-4)$. Pgp: P-glycoprotein; IA: injected activity

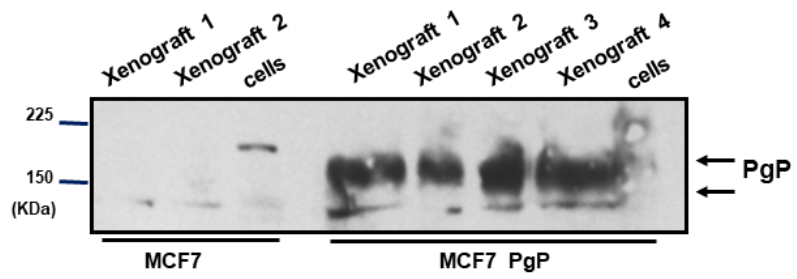

Figure 12. Expression of multidrug resistance proteins in human cancer cell lines and in tumor xenografts. Western blot analysis was used to examine the protein expression levels of the Pgp in the cell samples used to inoculate the mice and the xenografts developed. Pgp: P-glycoprotein

the expression of Pgp in xenografts ${ }^{[24]}$. In parallel to the tumors xenografts, we also analyzed samples of the cell suspension used to inoculate the animals. As can be seen in Figure 12, neither the MCF7 cells nor the xenografts presented Pgp expression, and, conversely, both MCF7 Pgp cells and respective xenografts had high levels of Pgp expression. This supports the idea that the difference in tumoral uptake of ${ }^{99 \mathrm{~m}} \mathrm{Tc}-\mathrm{TMEOP}$ observed in vivo is likely to be due to the efflux of the radiotracer by Pgp.

\section{DISCUSSION}

${ }^{99 \mathrm{~m}} \mathrm{Tc}$-radiopharmaceuticals such as ${ }^{99 \mathrm{~m}} \mathrm{Tc}$-sestamibi and ${ }^{99 \mathrm{~m}} \mathrm{Tc}$-tetrofosmin are widely applied as myocardial blood flow tracers for clinical purposes; however, their high liver uptake can interfere in the analysis of cardiac imaging, mainly in the inferior left ventricular wall ${ }^{[36-40]}$. Our group has developed two ${ }^{99 m} \mathrm{Tc}$ complexes, ${ }^{99 \mathrm{~m}} \mathrm{Tc}$-TMEOP and ${ }^{99 \mathrm{~m}} \mathrm{Tc}$-DMEOP, with an improved biological profile in comparison with the radiotracers in clinical use, and demonstrated that ${ }^{99 \mathrm{~m}} \mathrm{Tc}$-TMEOP accumulates intracellularly in mitochondria, and that its rapid liver clearance in mice can be explained by its transport by Pgp. These results, combined with the knowledge that similar cationic and lipophilic heart imaging agents have been explored for cancer detection and monitoring of tumor MDR function, led us to investigate the potential of these complexes for tumoral detection and MDR assessment in vivo.

Most tumoral cells present alterations in energy metabolism, increased transmembrane potential, and elevated reactive oxygen species generation, which can be explored as phenotypical traits for tumor targeting. In this context, we showed that there is a time-dependent uptake of ${ }^{99 \mathrm{~m}} \mathrm{Tc}$-DMEOP and ${ }^{99 \mathrm{~m}} \mathrm{Tc}$ - 
TMEOP in human tumoral cell lines of different origins - lung, breast, prostate, cervix, ovary, and skin. For cell lines from breast, lung, and prostate cancer and under the same experimental conditions, we showed that these two complexes have similar uptake and efflux profiles as ${ }^{99 m} \mathrm{Tc}-$ Sestamibi, and are typically more concentrated in cancer cells than ${ }^{99 \mathrm{~m}} \mathrm{Tc}$-tetrofosmin (except for H69 cell line). ${ }^{99 \mathrm{~m}} \mathrm{Tc}$-DMEOP and ${ }^{99 \mathrm{~m}} \mathrm{Tc}$ TMEOP have similar moderate lipophilicity values ( $\log P$ values of 0.58 and 0.61 , respectively), which are approximately half of the value for ${ }^{99 \mathrm{~m}} \mathrm{Tc}$-Sestamibi ( $\log P$ of 1.29). ${ }^{99 \mathrm{~m}} \mathrm{Tc}$-tetrofosmin presents the lowest lipophilicity among the four tested radiocomplexes, which might explain its overall lower cell uptake ${ }^{[41]}$. As already demonstrated for ${ }^{99 \mathrm{~m}} \mathrm{Tc}$-Sestamibi and other lipophilic cations, we showed that the cellular uptake of ${ }^{99 \mathrm{~m}} \mathrm{Tc}-\mathrm{DMEOP}$ and ${ }^{99 \mathrm{~m}} \mathrm{Tc}$-TMEOP is dependent of the mitochondrial membrane potential.

We then focused on the biological evaluation of these complexes in cancer cells lines with a MDR phenotype. Interestingly, we could show that ${ }^{99 \mathrm{~m}} \mathrm{Tc}$-DMEOP and ${ }^{99 \mathrm{~m}} \mathrm{Tc}$-TMEOP presented a reduced uptake in cancer cells lines expressing Pgp or MRP1, similarly to ${ }^{99 \mathrm{~m}} \mathrm{Tc}$-Sestamibi. For ${ }^{99 \mathrm{~m}} \mathrm{Tc}$-TMEOP, which seems to be a better substrate for Pgp and MRP1 than ${ }^{99 m} \mathrm{Tc}-\mathrm{DMEOP}$, we also demonstrated that, in the presence of a Pgp modulator, there is an increased uptake in the Pgp-expressing cancer cell line.

These encouraging results prompted a preliminary in vivo biological evaluation of ${ }^{99 \mathrm{~m}} \mathrm{Tc}$-TMEOP in nude mice with human cancer xenografts. We selected breast cancer cell lines, negative and positive for Pgp expression, and performed biodistribution studies. The in vivo results show that, in the mice model selected, as expected, there is a typical high and persistent heart uptake, with rapid liver clearance most likely via Pgp expressed in these tissues. The uptake of ${ }^{99 \mathrm{~m}} \mathrm{Tc}$-TMEOP in breast cancer xenografts is moderate to high with values of injected activity of $\sim 11 \%$ at $4 \mathrm{~h}$. When compared with the animals with the MDR tumor xenografts, the non-MDR xenografts present a higher uptake, although the difference is not statistically significant.

Taken together with the biochemical evidence of Pgp expression, these results seem to support that ${ }^{99 m}$ TcTMEOP is a substrate of Pgp in vivo. Further studies with tumor xenografts of different cancer types and with Pgp and MRP1 modulators will help to clarify the potential of ${ }^{99 \mathrm{~m}} \mathrm{Tc}-\mathrm{TMEOP}$ (and possibly ${ }^{99 \mathrm{~m}} \mathrm{Tc}$ DMEOP) for in vivo non-invasive tumoral detection and MDR assessment.

\section{DECLARATIONS}

\section{Acknowledgments}

We thank Prof. D Piwnica-Worms (MDAnderson Cancer Center, Texas,USA) for the kind gift of the MCF7/MDR1 and MCF7 neo cells line, and Elisabete Correia ( ${ }^{2} \mathrm{TN}$, Portugal) for excellent technical support.

\section{Authors' contributions}

Made substantial contributions to conception and design of the study and performed data analysis and interpretation: Mendes F, Gano L, Paulo A

Performed data acquisition: Mendes F, Gano L, Cunha S, Grilo J, Fernandes C

\section{Availability of data and materials}

Not applicable.

\section{Financial support and sponsorship}

This work was supported by Covidien (Petten, The Netherlands).

\section{Conflicts of interest}

All authors declared that there are no conflicts of interest. 


\section{Ethical approval and consent to participate}

All animal experiments were performed in compliance with Portuguese regulations for animal ethics and care.

\section{Consent for publication}

Not applicable.

\section{Copyright}

(c) The Author(s) 2020.

\section{REFERENCES}

1. World Health Organization. Fact sheet 39- All cancers. 2018. Available from https://gco.iarc.fr/today/data/factsheets/cancers/39-Allcancers-fact-sheet.pdf. [Last accessed on 15Feb 2020]

2. Gottesman MM, Pastan I. Biochemistry of multidrug resistance mediated by the multidrug transporter. Annu Rev Biochem 1993;62:385-427.

3. Gottesman MM. Mechanisms of cancer drug resistance. Annu Rev Med 2002;53:615-27.

4. Coley HM. Mechanisms and strategies to overcome chemotherapy resistance in metastatic breast cancer. Cancer Treat Rev 2008;34:378-90.

5. Sharma V, Piwnica-Worms D. Monitoring multidrug resistance P-glycoprotein drug transport activity with single-photon emission computed tomography and positron emission tomography radiopharmaceuticals in: contrast agents IIIRadiopharmaceuticals - from diagnostics to therapeutics. Top Curr Chem 2005:155-78.

6. Mohan HK, Miles KA. Cost-effectiveness of $99 \mathrm{mTc}-$ sestamibi in predicting response to chemotherapy in patients with lung cancer: systematic review and meta-analysis. J Nucl Med 2009;50:376-81.

7. Kannan P, John C, Zoghbi SS, Haldin C, Gottesman MM, et al. Imaging the function of P-glycoprotein with radiotracers: pharmacokinetics and in vivo applications. Clin Pharmacol Ther 2009;86:368-77.

8. Mendes F, Paulo A, Santos I. Metalloprobes for functional monitoring of tumor multidrug resistance by nuclear imaging. Dalton Trans 2011;40:5377-93.

9. Piwnica-Worms D, Chiu ML, Budding M, Kronauge JF, Kramer RA, et al. Functional imaging of multidrug-resistant P-glycoprotein with an organotechnetium complex. Cancer Res 1993;53:977-84.

10. Ballinger JR, Bannerman J, Boxen I, Firby P, Hartman NG, et al. Technetium-99m-tetrofosmin as a substrate for P-glycoprotein: in vitro studies in multidrug-resistant breast tumor cells. J Nucl Med 1996;37:1578-82.

11. Ballinger JR, Muzzammil T, Moore MJ. Technetium-99m-furifosmin as an agent for functional imaging of multidrug resistance in tumors. J Nucl Med 1997;38:1915-9.

12. Rao VV, Herman LW, Kronauge JF, Piwnica-Worms D. A novel areneisonitrile Tc complex inhibits the transport activity of MDR P-glycoprotein. Nucl Med Biol 1998;25:225-32.

13. Bolzati C, Carta D, Gandin V, Marzano C, Morellato N, et al. (99m)Tc(N)-DBODC(5), a potential radiolabeled probe for SPECT of multidrug resistance: in vitro study. J Biol Inor Chem 2013;18:523-38.

14. Chen S, Zhang Y, Li X, Jia H, Lu J. The evaluations of ${ }^{99 \mathrm{~m}} \mathrm{Tc}$ cyclopentadienyl tricarbonyl triphenyl phosphonium cation for multidrug resistance. Bioorg Med Chem Lett 2017;27:3551-4.

15. Schillaci O, Spanu A, Madeddu G. [99mTc]sestamibi and [99mTc]tetrofosmin in oncology: SPET and fusion imaging in lung cancer, malignant lymphomas and brain tumors. Q J Nucl Med Mol Imaging 2005;49:133-44.

16. Wang XS, Zhang YJ, Liu XL, Zhou ZR, Hu CS, et al. The role of technetium-99m methoxyisobutyl isonitrile scintigraphy in predicting the therapeutic effect of chemotherapy against nasopharyngeal carcinoma. Cancer 2011;117:2435-41.

17. Saggiorato E, Angusti T, Rosas R, Martinese M, Finessi M, et al. 99mTc-MIBI Imaging in the presurgical characterization of thyroid follicular neoplasms: relationship to multidrug resistance protein expression. J Nucl Med 2009;50:1785-93.

18. Duan XY, Wang JS, Liu M, Guo YM. Technetium-99m-hexakis-2-methoxyisobutylisonitrile scintigraphy and multidrug resistance-related protein expression in human primary lung cancer. Ann Nucl Med 2008;22:49-55.

19. Mubashar M, Harrington KJ, Chaudhary KS, Lalani E, Stamp GW, et al. 99mTc-sestamibi imaging in the assessment of toremifene as a modulator of multidrug resistance in patients with breast cancer. J Nucl Med 2002;43:519-25.

20. Takamura Y, Miyoshi Y, Taguchi T, Noguchi S. Prediction of chemotherapeutic response by Technetium 99m--MIBI scintigraphy in breast carcinoma patients. Cancer 2001;92:232-9.

21. Kurata S, Ushijima K, Kawahara A, Kaida H, Kawano K, et al. Assessment of 99mTc-MIBI SPECT(/CT) to monitor multidrug resistancerelated proteins and apoptosis-related proteins in patients with ovarian cancer: a preliminary study. Ann Nucl Med 2015;29:643-9.

22. Gomes CM, Welling M, Que I, Henriquez NV, van der Pluijmet G, al. Functional imaging of multidrug resistance in an orthotopic model of osteosarcoma using 99mTc-sestamibi. Eur J Nucl Med Mol Imaging 2007;34:1793-803.

23. Rowe SP, Gorin MA, Solnes LB, Ball MW, Choudhary A, et al. Correlation of ${ }^{99 \mathrm{~m}} \mathrm{Tc}$-sestamibi uptake in renal masses with mitochondrial content and multi-drug resistance pump expression. EJNMMI Res 2017;7:80.

24. Liu S, Kim YS, Zhai S, Shi J, Hou G. Evaluation of (64)Cu(DO3A-xy-TPEP) as a potential PET radiotracer for monitoring tumor multidrug resistance. Bioconjug Chem 2009;20:790-8. 
25. Maria L, Cunha S, Videira M, Gano L, Paulo A, et al. Rhenium and technetium tricarbonyl complexes anchored by pyrazole-based tripods: novel lead structures for the design of myocardial imaging agents. Dalton Trans 2007:3010-9.

26. Maria L, Fernandes C, Garcia R, Gano L, Paulo A, et al. Tris(pyrazolyl)methane 99mtc tricarbonyl complexes for myocardial imaging. Dalton Trans 2009:603-6.

27. Mendes F, Gano L, Fernandes C, Paulo A, Santos I. Studies of the myocardial uptake and excretion mechanisms of a novel $99 \mathrm{mTc}$ heart perfusion agent. Nucl Med Biol 2011;39:209-13.

28. Goethals LR, Santos I, Caveliers V, Paulo A, De Geeter F, et al. Rapid hepatic clearance of 99mTc-TMEOP: a new candidate for myocardial perfusion imaging. Contrast Media Mol Imaging 2011;6:178-88.

29. Bolzati C, Uccelli L, Boschi A, Malagò E, Duatti A, et al. Synthesis of a novel class of nitrido Tc-99m radiopharmaceuticals with phosphino-thiol ligands showing transient heart uptake. Nucl Med Biol 2000;27:369-74.

30. Modica-Napolitano JS, Aprille JR. Basis for the selective cytotoxicity of rhodamine 123. Cancer Res 1987;47:4361-5.

31. Bonnet S, Archer SL, Allalunis-Turner J, Haromy A, Beaulieu C, et al. A mitochondria- $\mathrm{K}^{+}$channel axis is suppressed in cancer and its normalization promotes apoptosis and inhibits cancer growth. Cancer Cell 2007;11:37-51.

32. Pancrazio JJ, Tabbara IA, Kim YI. Voltage-activated $\mathrm{K}^{+}$conductance and cell proliferation in small-cell lung cancer. Anticancer Res $1993 ; 13: 1231-4$.

33. Wonderlin WF, Woodfork KA, Strobl JS. Changes in membrane potential during the progression of MCF-7 human mammary tumor cells through the cell cycle. J Cell Physiol 1995;165:177-85.

34. Reed PW. Ionophores. Methods Enzymol 1979;55:435-54

35. Hanstein WG. Uncoupling of oxidative phosphorylation. Biochim Biophys Acta 1976;456:129-48.

36. Germano G, Chua T, Kiat H, Areeda JS, Berman DS. A quantitative phantom analysis of artifacts due to hepatic activity in technetium99m myocardial perfusion SPECT studies. J Nucl Med 1994;35:356-9.

37. Kailasnath P, Sinusas AJ. Technetium-99m-labeled myocardial perfusion agents: are they better than thallium-201? Cardiol Rev 2001;9:160-72.

38. Kapur A, Latus KA, Davies G, Dhawan RT, Eastick S, et al. A comparison of three radionuclide myocardial perfusion tracers in clinical practice: the ROBUST study. Eur J Nucl Med Mol Imaging 2002;29:1608-16.

39. Llaurado JG. The quest for the perfect myocardial perfusion indicator...still a long way to go. J Nucl Med 2001;42:282-4.

40. Parker JA. Cardiac nuclear medicine in monitoring patients with coronary heart disease. Semin Nucl Med 2001;31:223-37.

41. Kim YS, He Z, Hsieh WY, Liu S. Impact of bidentate chelators on lipophilicity, stability, and biodistribution characteristics of cationic 99mTc-nitrido complexes. Bioconjug Chem 2007;18:929-36. 